Y/TS-1729

\section{$Y-12$}
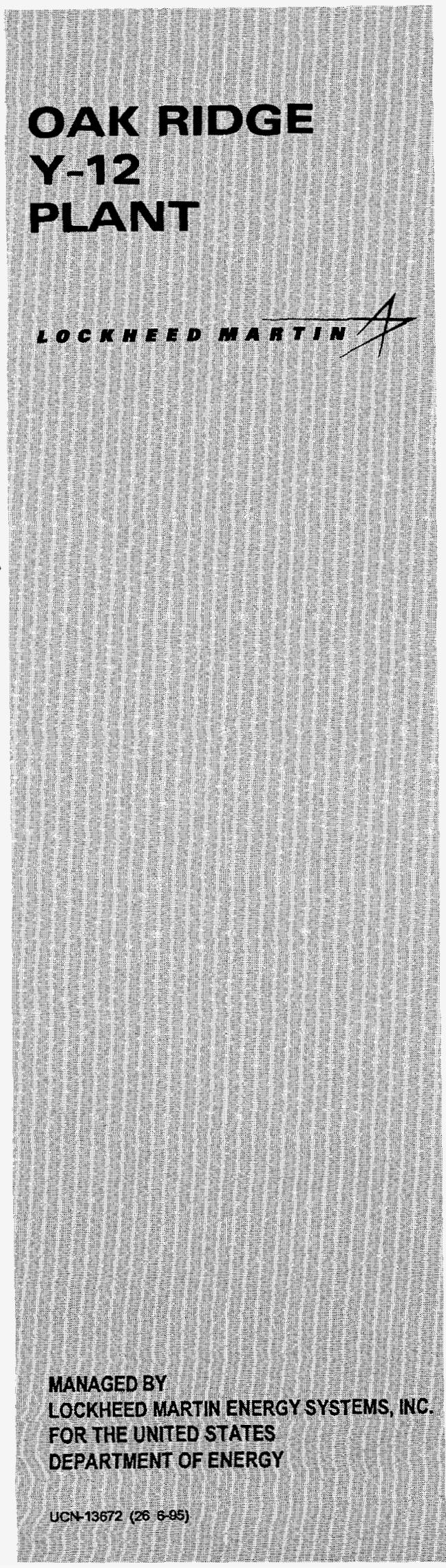

\section{ANALYTICAL SERVICES ORGANIZATION}

UNION VALLEY SAMPLE PREPARATION FACILITY

POLYCHLORINATED BIPHENYL (PCB)

ANNUAL INVENTORY DOCUMENT

EPA IDENTIFICATION NUMBER TNR0000027253

Period covering: January 1, 1997, to January 1, 1998

Bridget J. Brown

Environmental Compliance Department

Environmental, Safety and Health Organization

June 1998

Prepared by the

Oak Ridge Y-12 Plant

Oak Ridge, Tennessee 37831

Managed by

LOCKHEED MARTIN ENERGY SYSTEMS, INC.

for the U.S. Department of Energy

under Contract DE-AC05-84OR21400 


\section{DISCLAIMER}

This report was prepared as an account of work sponsored by an agency of the United States Government. Neither the United States Government nor any agency thereof, nor any of their employees, makes any warranty, express or implied, or assumes any legal liability or responsibility for the accuracy, completeness, or usefulness of any information, apparatus, product, or process disclosed, or represents that its use would not infringe privately owned rights. Reference herein to any specific commercial product, process, or service by trade name, trademark, manufacturer, or otherwise, does not necessarily constitute or imply its endorsement, recommendation, or favoring by the United States Government or any agency thereof. The views and opinions of authors expressed herein do not necessarily state or reflect those of the United States Government or any agency thereof. 


\section{DISCLAIMER}

This report was prepared as an account of work sponsored by an agency of the United States Government. Neither the United States Government nor any agency thereof, nor any of their employees, make any warranty, express or implied, or assumes any legal liability or responsibility for the accuracy, completeness, or usefulness of any information, apparatus, product, or process disclosed, or represents that its use would not infringe privately owned rights. Reference herein to any specific commercial product, process, or service by trade name, trademark, manufacturer, or otherwise does not necessarily constitute or imply its endorsement, recommendation, or favoring by the United States Government or any agency thereof. The views and opinions of authors expressed herein do not necessarily state or reflect those of the United States Government or any agency thereof. 


\section{DISCLAIMER}

Portions of this document may be illegible in electronic image products. Images are produced from the best available original document. 
Mr. R. J. Spence

Y-12 Site Manager

Department of Energy, Oak Ridge Operations

Post Office Box 2001

Oak Ridge, Tennessee 37831

Dear Mr. Spence:

Contract DE-AC05-84OR21400, Polychlorinated Biphenyl (PCB) Annual

Inventory Document from January 1, 1997, to January 1, 1998, at the Analytical

Services Organization, Union Valley Sample Preparation Facility (UVSPF)

Enclosed is the Analytical Services Organization Union Valley Sample Preparation Facility

Polychlorinated Biphenyl (PCB) Annual Inventory Document (Y/TS-1729). The UVSPF Environmental Protection Agency PCB identification number is TNR0000027253. The purpose of this report is to fulfill the record keeping requirements set forth in Title 40, Code of Federal Regulations, Part 761.180(a), as specified for facilities using and storing PCBs. This document provides the UVSPF information for the period January 1, 1997, to January 1, 1998, concerning the type and amount of PCB waste generated, disposed of, and held in storage.

If you have any questions or comments concerning the document, please contact B. J. Brown at 574-3874.

Very truly yours,<smiles>CC(C)CC(C)C1CCCC12CCCC2</smiles>

T. R. Butz

Y-12 Plant Manager

TRB:Ir

Enclosure: As Stated 
Mr. R. J. Spence, DOE-ORO

Page 2

June 29, 1998

cc/enc: $\quad$ E. M. Atkins, DOE-ORO

B. C. Brown

P. R. Goins/M. S. Blalock

H. S. Hackler

J. E. Heiskell/K. D. Delius/E. J. Barnett

S. E. Justice

C. M. LaBorde, Bechtel Jacobs Company

D. D. Markelonis, Bechtel Jacobs Company

S. E. Rathke/B. J. Brown

R. L. Sampsel

L. M. Sparks, DOE-ORO

A. L. Yeager

Y-12 Record Services (3)

EC Document Control-RC

cc: R. E. Bell

T. R. Butz

L. A. Felton

C. C. Hill

J. E. Stone/J. E. Powell 
Enclosure

Letter, Butz to Spence

Dated: June 29, 1998

Contract DE-AC05-84OR21400, Polychlorinated Biphenyl (PCB) Annual Inventory Document from January 1, 1997, to January 1, 1998, at the Analytical Services Organization, Union Valley Sample Preparation Facility (UVSPF) 
Y/TS-1729

\title{
ANALYTICAL SERVICES ORGANIZATION \\ UNION VALLEY SAMPLE PREPARATION FACILITY \\ POLYCHLORINATED BIPHENYL (PCB) \\ ANNUAL INVENTORY DOCUMENT
}

EPA IDENTIFICATION NUMBER TNR0000027253

Period covering: January 1, 1997, to January 1, 1998

Date of Issue: June 1998

Bridget J. Brown

Environmental Compliance Department

Environmental, Safety and Health Organization

\author{
Prepared by the \\ Oak Ridge Y-12 Plant \\ Oak Ridge, Tennessee 37831 \\ Managed by \\ LOCKHEED MARTIN ENERGY SYSTEMS, INC. \\ for the \\ U.S. DEPARTMENT OF ENERGY \\ under Contract DE-AC05-840R21400
}


EXECUTIVE SUMMARY

A. INTRODUCTION 2

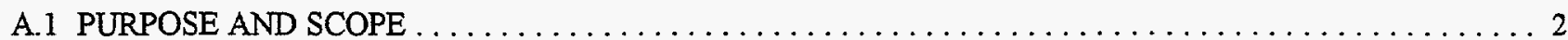

A.2 STORAGE LOCATIONS OF PCB WASTE ( $>50$ PPM) AT Y-12 $\ldots \ldots \ldots \ldots \ldots \ldots \ldots \ldots \ldots \ldots \ldots$

B. PCB WASTE ACTIVITY INVENTORY FOR JANUARY 1, 1997, TO JANUARY 1, $1998 \ldots \ldots \ldots \ldots$

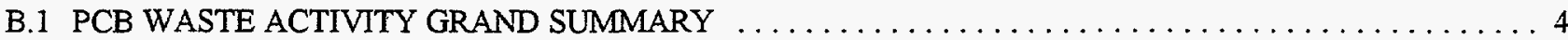

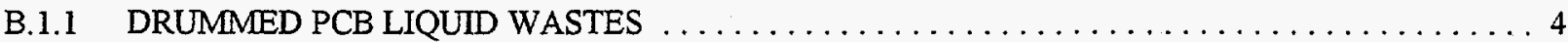

B.1.2 DRUMMED PCB SOLID WASTES $\ldots \ldots \ldots \ldots \ldots \ldots \ldots \ldots \ldots \ldots \ldots \ldots \ldots \ldots \ldots \ldots \ldots$

B.2 BEGINNING PCB WASTE INVENTORY JANUARY $1,1997 \ldots \ldots \ldots \ldots \ldots \ldots \ldots \ldots \ldots \ldots \ldots$

B.2.1 DRUMMED PCB LIQUID WASTES $\ldots \ldots \ldots \ldots \ldots \ldots \ldots \ldots \ldots \ldots \ldots \ldots \ldots \ldots \ldots$

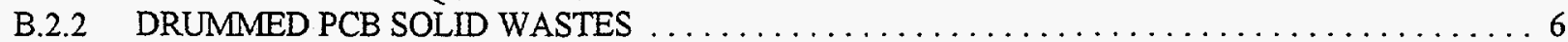

B.3 PCB WASTE CONSOLIDATED OR TRANSFERRED FROM JANUARY 1, 1997, TO JANUARY 1, 1998 . 7

B.3.1 DRUMMED PCB LIQUIDS CONSOLIDATED $\ldots \ldots \ldots \ldots \ldots \ldots \ldots \ldots \ldots \ldots \ldots \ldots \ldots \ldots$

B.3.2 DRUMMED PCB SOLIDS CONSOLIDATED $\ldots \ldots \ldots \ldots \ldots \ldots \ldots \ldots \ldots \ldots \ldots \ldots$

B.4 PCB WASTE GENERATED FROM JANUARY 1 , 1997, TO JANUARY $1,1998 \ldots \ldots \ldots \ldots \ldots \ldots$

B.4.1 DRUMMED PCB LIQUID WASTES $\ldots \ldots \ldots \ldots \ldots \ldots \ldots \ldots \ldots \ldots \ldots \ldots \ldots \ldots$

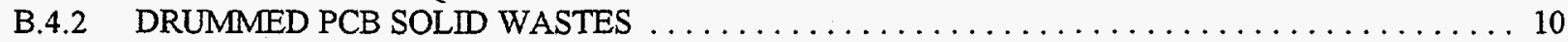

B.5 DRUMS GENERATED FROM CONSOLIDATION ACTIVITIES $\ldots \ldots \ldots \ldots \ldots \ldots \ldots \ldots \ldots \ldots \ldots \ldots$

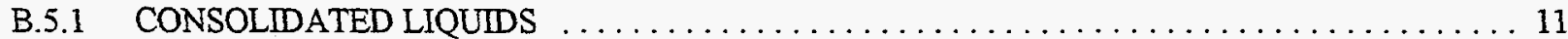

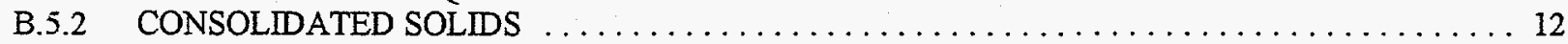

B.6 PCB WASTE SHIPPED FROM JANUARY 1,1997 , TO JANUARY $1,1998 \ldots \ldots \ldots \ldots \ldots \ldots \ldots \ldots 13$

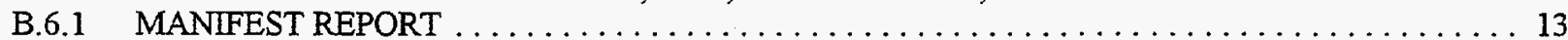

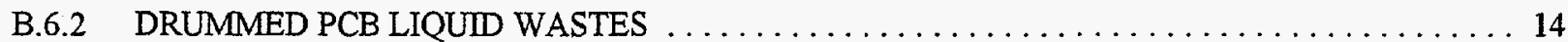

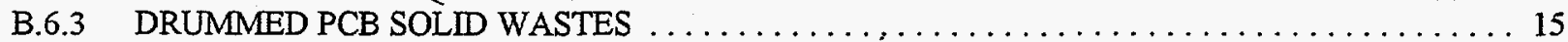

B.7 ENDING PCB WASTE INVENTORY JANUARY $1,1998 \ldots \ldots \ldots \ldots \ldots \ldots \ldots \ldots \ldots \ldots \ldots \ldots \ldots$

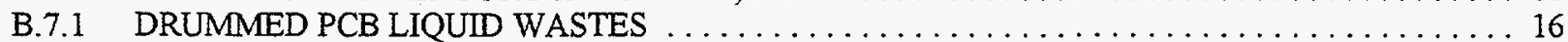

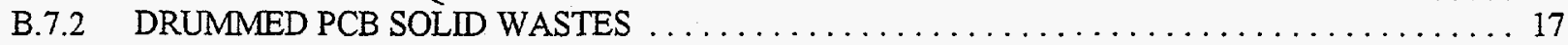

APPENDIX A: VERIFICATION LOG FOR SHIPMENTS BY INDEPENDENT TRANSPORTERS

APPENDIX B: INVENTORY ADJUSTMENTS

APPENDIX C: ANNUAL RECORDS 


\section{EXECUTIVE SUMMARY}

The Analytical Services Organization (ASO), Union Valley Sample Preparation Facility (UVSPF), provides analytical testing in support of the Department of Energy (DOE), Oak Ridge Operations (ORO), and associated sites. Samples generated on the Oak Ridge Reservation (ORR) are routinely received at the UVSPF for analytical evaluation/identification. Many of these samples are polychlorinated biphenyl $(\mathrm{PCB}$ ) regulated from a source or being sent to the facility to determine PCB content. PCB laboratory wastes in solid and liquid form are generated during the evaluation of these materials, requiring the UVSPF staff to maintain formal storage areas for staging the materials prior to off-site shipment for disposal. The purpose of this report is to fulfill the requirements set forth in Title 40, Code of Federal Regulations (CFR), Part 761.180(a), Subpart J, which requires owners or operators of a facility using or storing PCBs to prepare an annual inventory document by July 1 of the current year which covers the previous calendar year.

This report provides documentation of the inventory of $\mathrm{PCB}$ materials/wastes that were generated, stored for disposal, and shipped off site for disposal for the period January 1,1997 , to January 1,1998 . The following is a summary of materials/wastes subject to the aforementioned reporting requirements.

\section{$\underline{\text { PCB Wastes }}$}

\section{Mass}

Drummed PCB Solid Waste Generated

Drummed PCB Solids Consolidated

Drummed PCB Solids Generated from Consolidation Activities

$0 \mathrm{~kg}$

Drummed PCB Solid Waste Shipped for Disposal

$0 \mathrm{~kg}$

Drummed PCB Solid Waste Disposed

Drummed PCB Solid Waste Inventory Dated January 1, 1998

$0 \mathrm{~kg}$

Drummed PCB Liquid Waste Generated

Drummed PCB Liquids Consolidated

Drummed PCB Liquids Generated from Consolidation Activities

$0 \mathrm{~kg}$

Drummed PCB Liquid Waste Shipped for Disposal

$0 \mathrm{~kg}$

Drummed PCB Liquid Waste Disposed

Drummed PCB Liquid Waste Inventory Dated January 1, 1998

$0 \mathrm{~kg}$

$0 \mathrm{~kg}$ 
Page No. 2

\section{A. INTRODUCTION}

\section{A.1 PURPOSE AND SCOPE}

Polychlorinated biphenyls (PCBs) are considered a toxic substance that presents an unreasonable risk of injury to human health and the environment. As such, when the United States Congress passed the Toxic Substances Control Act (TSCA) in 1977, the Act included provisions which directed the Environmental Protection Agency (EPA) staff to phase out the manufacture, processing, distribution in commerce, and use of PCBs. In response to this mandate, the EPA staff has promulgated regulations in 40 CFR, Part 761, restricting the manufacture, processing, distribution, use, storage, and disposal of PCBs.

These regulations specifically address the use of PCBs at concentrations of 50 parts per million (ppm) or greater in research and development (R\&D) activities. Analytical chemistry methods are included in the EPA interpretation of what constitutes an R\&D activity, rendering all analytical laboratories subject to PCB regulation. In addition, the regulations are specific with respect to record keeping requirements, approved storage facilities, acceptable disposal methods, and activities involving the handling of materials/wastes containing PCBs.

The ASO UVSPF provides analytical testing in support of the DOE ORO. Samples generated on the ORR are routinely received at the UVSPF for analytical evaluation. Many of these samples are PCB regulated from a source or being sent to the facility to determine PCB content. PCB laboratory wastes in solid and liquid form are generated during the evaluation of these materials, requiring the UVSPF staff to maintain formal storage areas for staging the materials prior to offsite shipment for disposal. Since the ASO UVSPF is not located on the ORR, the Oak Ridge Reservation Polychlorinated Biphenyl Federal Facilities Compliance Agreement does not apply; therefore, the ASO is responsible for maintaining strict adherence to the regulations outlined in 40 CFR 761.

The purpose of this report is to fulfill the record keeping requirements set forth in $40 \mathrm{CFR}$ Part 761.180(a). This provision requires that an owner or operator of a facility using or storing PCBs develop and maintain records on the disposition of PCBs and PCB items, and prepare an annual inventory document by July 1 of the current year which covers the previous calendar year. The information included in this report reflects the ASO UVSPF PCB inventory activities beginning January 1, 1997, through January 1, 1998. 
鄫

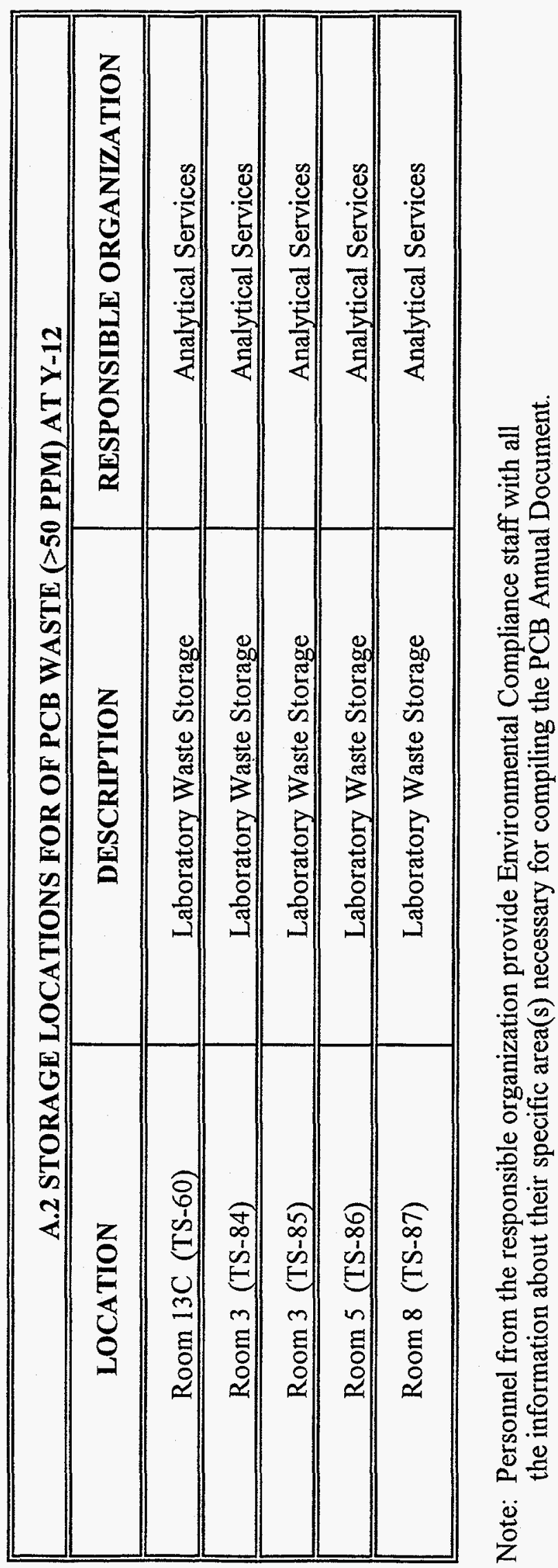


B. PCB WASTE ACTIVITY INVENTORY FOR JANUARY 1, 1997, TO JANUARY 1, 1998

\section{B.1 PCB WASTE ACTIVITY GRAND SUMMARY}

\section{B.1.1 DRUMMED PCB LIQUID WASTES}

\begin{tabular}{||l|c|c||}
\hline \multicolumn{1}{|c|}{ DRUMMED PCB WASTES (LIQUD) } \\
\hline \multicolumn{1}{|c|}{ TOTAL QUANTITY } & TOTAL KULOGRAMS \\
\hline $\begin{array}{l}\text { BEGINNING PCB WASTE } \\
\text { INVENTORY JANUARY 1, 1997 }\end{array}$ & 0 & 0 \\
\hline $\begin{array}{l}\text { GENERATED FROM } \\
\text { JANUARY 1, 1997, TO } \\
\text { JANUARY 1, 1998 }\end{array}$ & 4 & 371 \\
\hline $\begin{array}{l}\text { DRUMS TRANSFERRED OR } \\
\text { CONSOLIDATED }\end{array}$ & 0 & 0 \\
\hline $\begin{array}{l}\text { DRUMS GENERATED FROM } \\
\text { CONSOLDATION ACTIVITES }\end{array}$ & 0 & 0 \\
\hline $\begin{array}{l}\text { DRUMS SHIPPED FOR DISPOSAL } \\
\text { FROM JANUARY 1, 1997, TO } \\
\text { JANUARY 1, 1998 }\end{array}$ & 0 & 0 \\
\hline $\begin{array}{l}\text { ENDING PCB WASTE INVENTORY } \\
\text { JANUARY 1, 1998 }\end{array}$ & 4 & \\
\hline
\end{tabular}

\section{B.1.2 DRUMMED PCB SOLID WASTES}

\begin{tabular}{|l|c|c|}
\hline \multicolumn{1}{|c|}{ DRUMMED PCB WASTES (SOLD) } \\
\hline $\begin{array}{l}\text { BEGINNING PCB WASTE } \\
\text { INVENTORY JANUARY 1, 1997 }\end{array}$ & TOTAL QUANTITY & TOTAL KILOGRAMS \\
\hline $\begin{array}{l}\text { GENERATED FROM } \\
\text { JANUARY 1, 1997, TO } \\
\text { JANUARY 1, 1998 }\end{array}$ & 4 & 0 \\
\hline $\begin{array}{l}\text { DRUMS CONSOLIDATED } \\
\text { DRUMS GENERATED FROM } \\
\text { CONSOLIDATION ACTTITES }\end{array}$ & 0 & 190 \\
\hline $\begin{array}{l}\text { SHIPPED FOR DISPOSAL FROM } \\
\text { JANUARY 1, 1997, TO } \\
\text { JANUARY 1, 1998 }\end{array}$ & 0 & 0 \\
\hline $\begin{array}{l}\text { ENDING PCB WASTE INVENTORY } \\
\text { JANUARY 1, 1997 }\end{array}$ & 0 & 0 \\
\hline
\end{tabular}




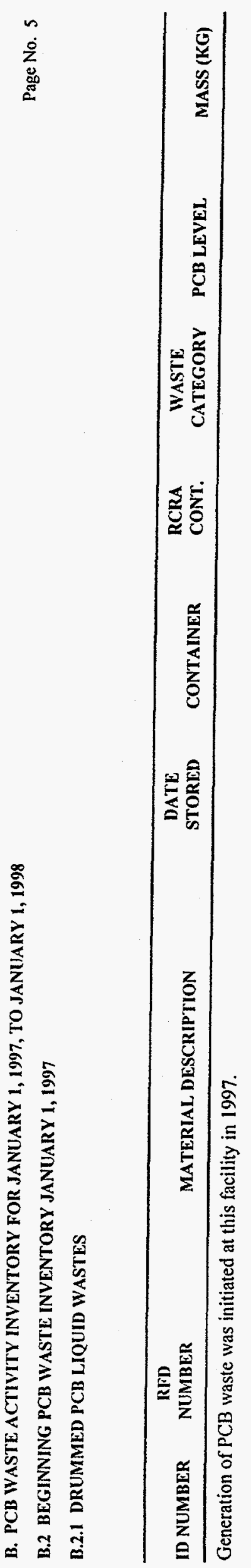




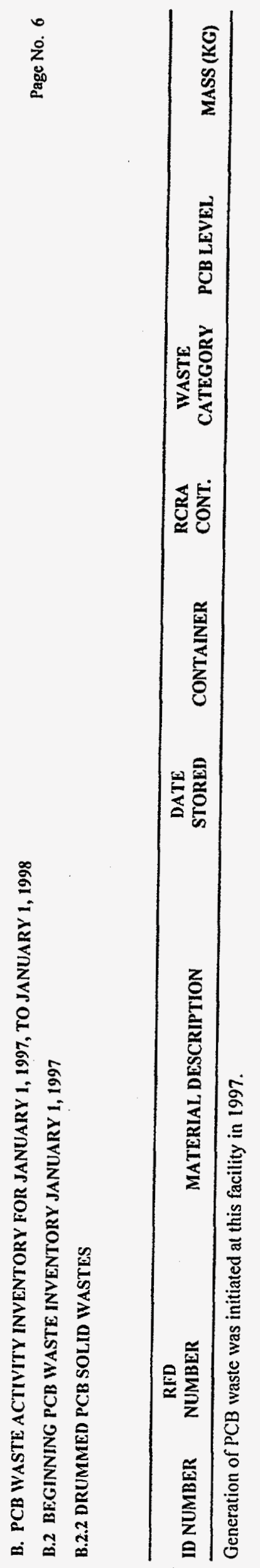




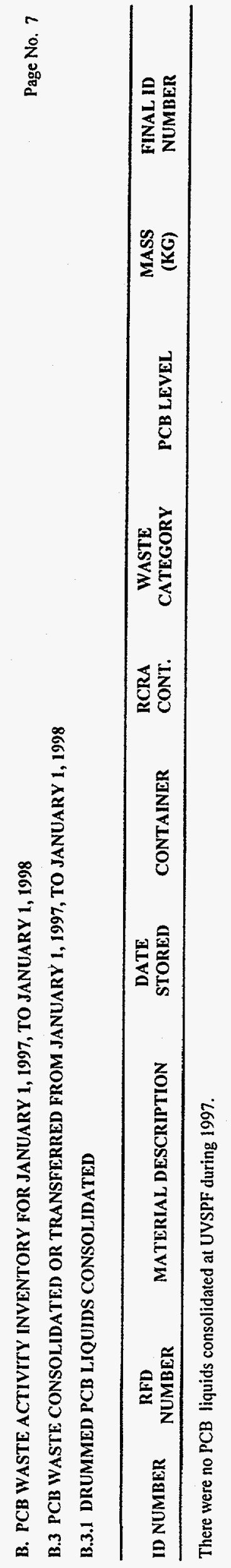




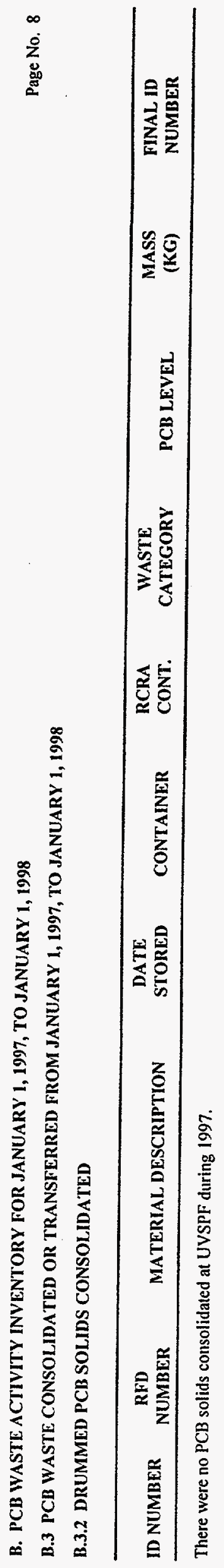




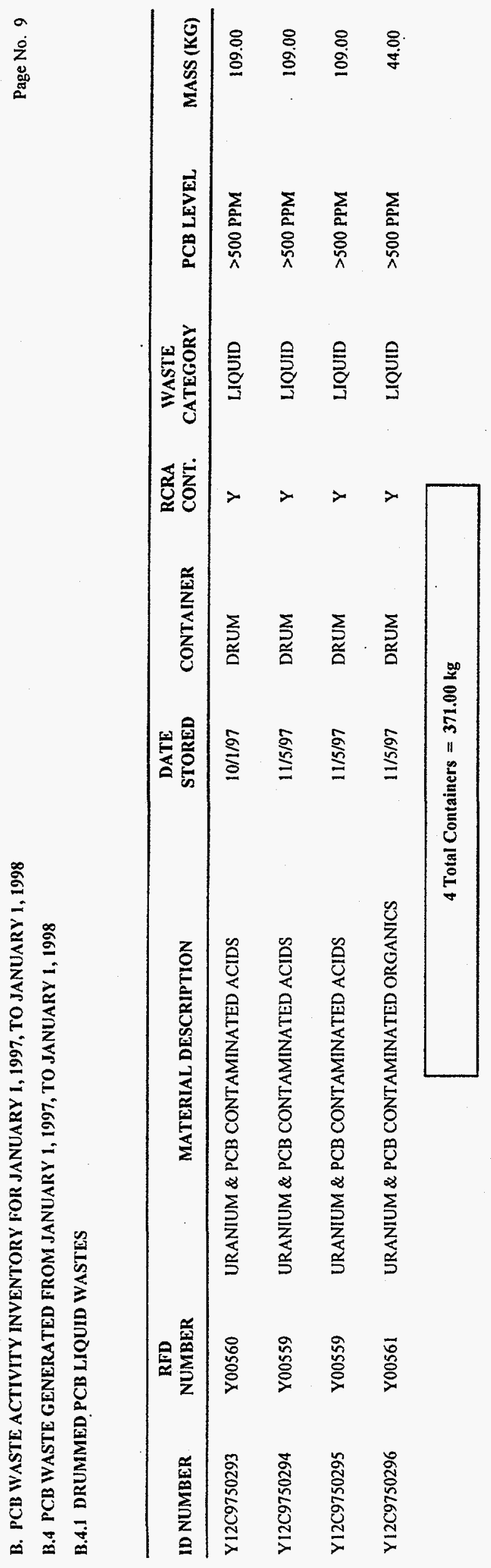




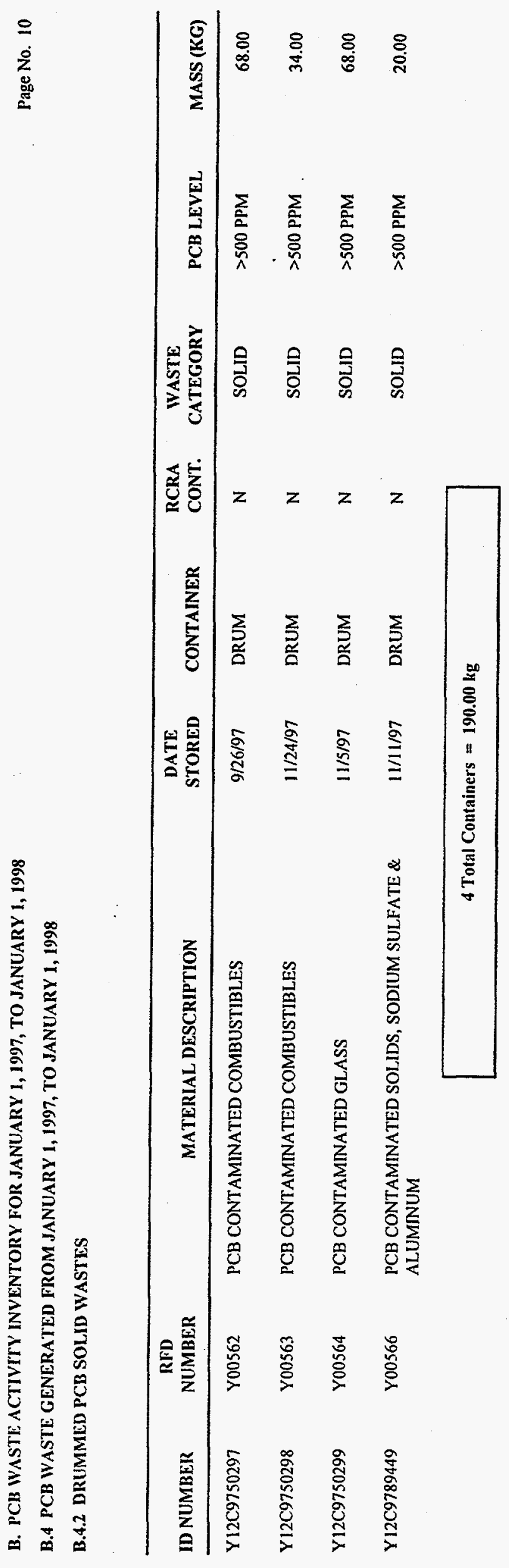




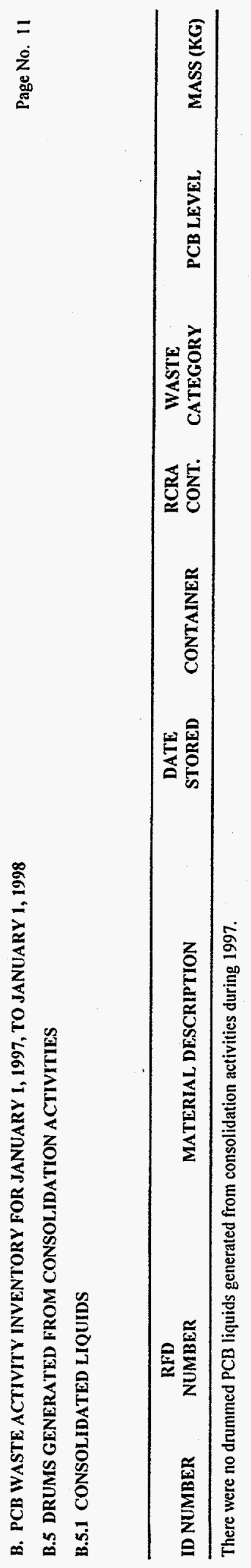




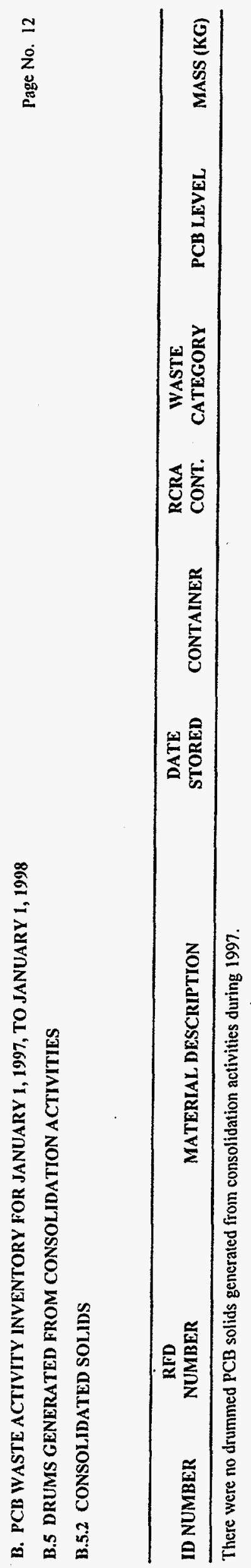


$m$
$\dot{0}$
$\dot{2}$
0
0
0

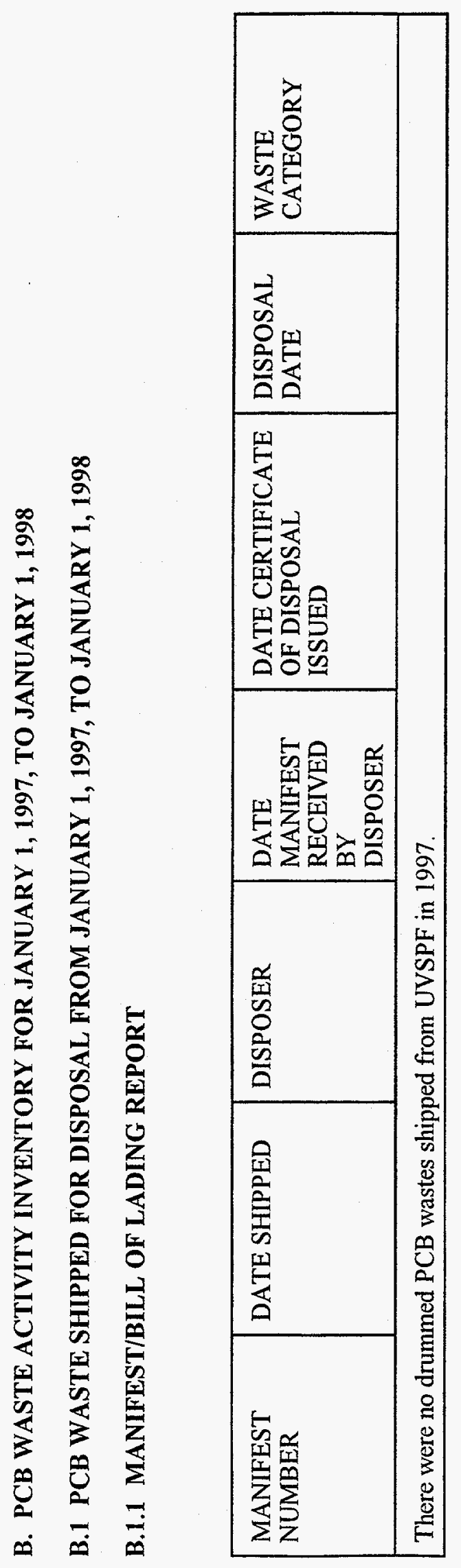




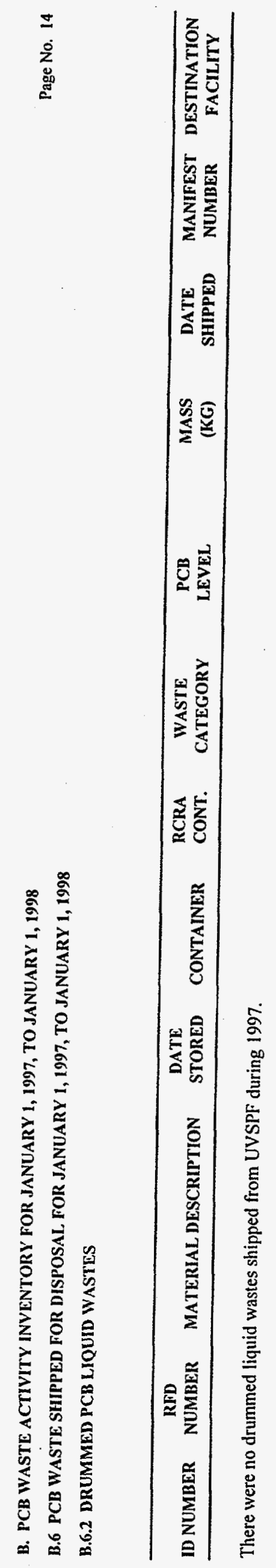




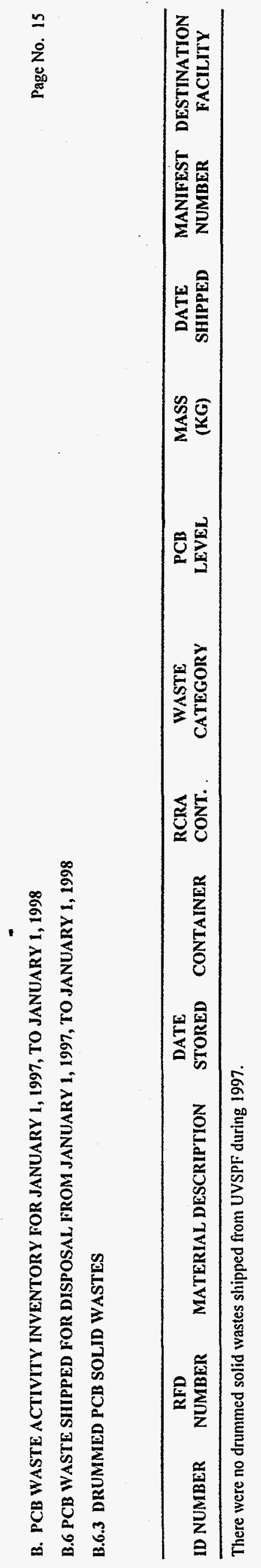




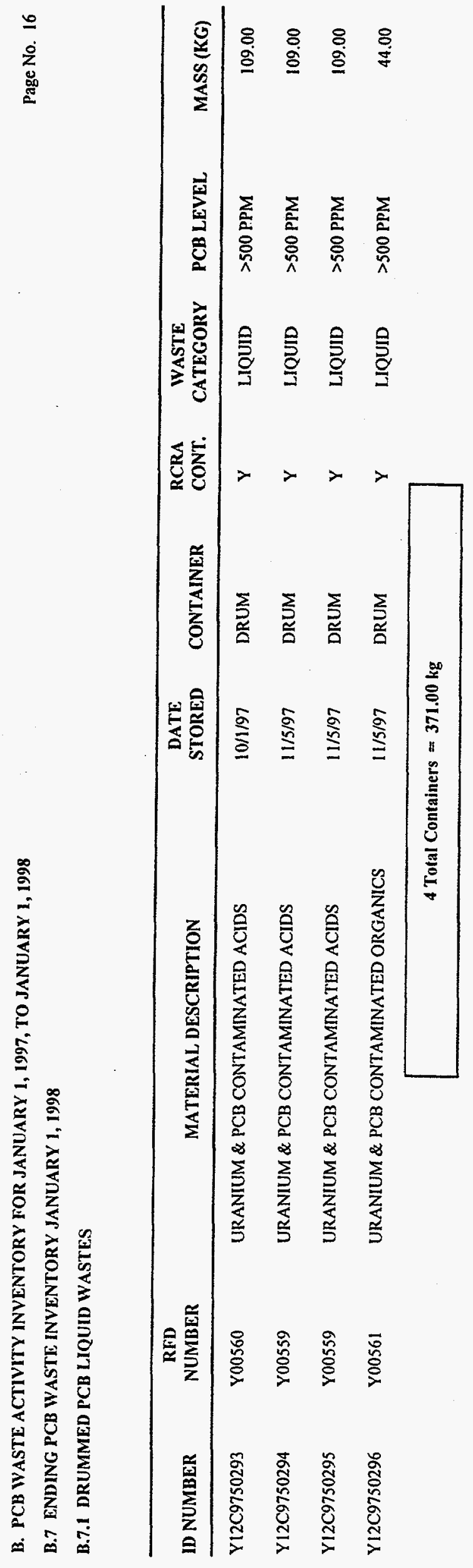




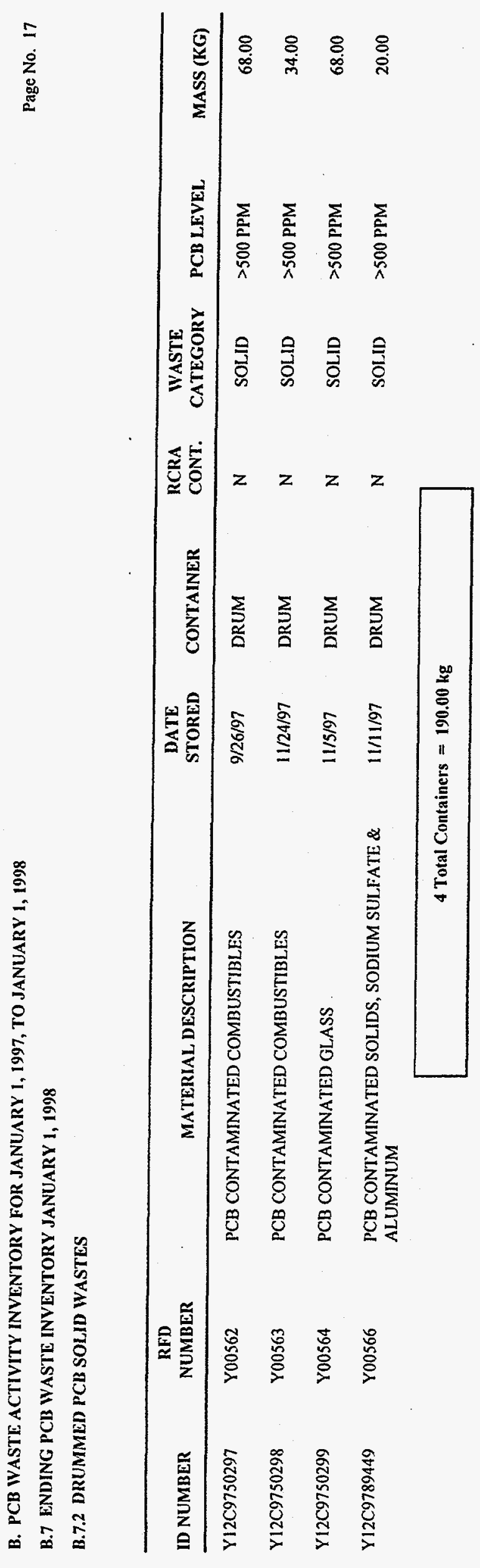




\section{APPENDIX A}

VERIFICATION LOG FOR SHIPMENTS BY INDEPENDENT TRANSPORTERS 
There were no PCB shipments to commercial disposers by independent transporters from the Y-12 Plant during 1997; therefore, no PCB Telephone Log was prepared. 


\section{APPENDIX B}

INVENTORY ADJUSTMENTS 
Prior to 1997, UVSPF did not generate PCB wastes; therefore, no corrections/adjustments were needed on the 1997 inventory. 


\section{APPENDIX C}

ANNUAL RECORDS 
There were no PCB waste shipments from UVSPF in 1997; therefore, manifests and certificates of disposal were not generated. 


\section{Distribution:}

E. M. Atkins, DOE-ORO

B. C. Brown

P. R. Goins/M. S. Blalock

H. S. Hackler

J. E. Heiskell/K. D. Delius/E. J. Barnett

S. E. Justice

C. M. LaBorde, Bechtel Jacobs Company

D. D. Markelonis, Bechtel Jacobs Company

S. E. Rathke./B. J. Brown

R. L. Sampsel

L. M. Sparks, DOE-ORO

A. L. Yeager

Y-12 Record Services (3)

EC Document Center-RC 